Editorial

\title{
Verdades mentirosas
}

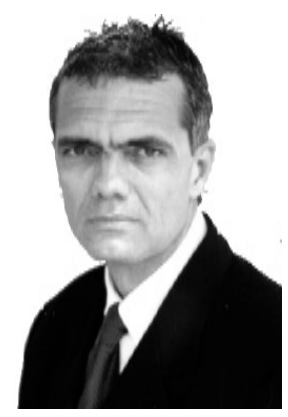

Marco Antonio Guimarães da Silva,Med.Dr.Sci. marco@atlanticaedu.com.br

Há poucas coisas que não devem ser admitidas em público. A volatilização de gases oriundos do intestino é uma delas e deve permanecer anônima. De autoria incógnita, é constrangimento menor. Mas a assunção da culpa acaba por elevar o evento e o culpado a dimensóes incomensuráveis de vergonha e humilhação.

Mas nem todas as culpas assumidas causam embaraço: o reconhecimento público do erro, se acompanhado de justo arrependimento e providências circunstanciais, é uma mostra de coragem e dignidade. Essa atitude de humildade, longe de fragilizar a imagem do culpado no meio social, acaba por humanizar as relaçóes entre ele e a sua comunidade.

Obviamente, a não assunção de um erro ou de uma culpa implica em uma mentira que, à dependência de sua magnitude, pode, eventualmente, não ter conseqüências ou talvez incomodar, no caso citado no primeiro parágrafo, quando muito, aqueles com olfato apurado. O problema está na perpetuação da mentira e na sua utilização como ato rotineiro. O mentiroso acaba por acreditar que a sua mentira é mais pura das verdades e não se dá conta dessa transformação. É o que chamamos de "verdade mentirosa".

Existem situações em que não se pode admitir a prática da "verdade mentirosa", porque elas podem pôr em risco a própria subsistência humana.

Essas "verdades mentirosas" estáo nos mais diversos setores da sociedade, que não admitem o erro de náo cumprirem com competência a sua funçáo. Deixam, por exemplo, que leite e alimentos contaminados sejam vendidos para o público; ou que as encostas desmoronem, causando transtornos e mortes, como as assistidas e vividas por todos os que vivem no Rio de Janeiro.

A área da pesquisa e da produção cientifica não é exceção. Afinal, ela também é exercida pelo ser humano, que mente e erra, e as conseqüências de seus erros e mentiras podem igualmente ser fatais. Sempre cito, quando quero explicar para meus alunos os erros alfa e beta, o gravíssimo equívoco cometido por uma pesquisa, realizada nos EUA, que dizia que associar um sal medicamentoso a um contraceptivo oral não causava formaçôes neoplásicas. A pesquisa partia do pressuposto que não haveria diferenças estatísticas significativas ( $\mathrm{p}<0,005$ ) entre os grupos controle e experimental. O erro nesse tipo de pesquisa, como sabem todos os que trabalham com a investigação, é o Tipo II ou Beta, ou seja, afirmar que não existem diferenças, quando elas, na realidade, existem. $\mathrm{E}$ elas existiam. No caso em questão, porque o poder do teste estatístico estabelecido estava baixo e não conseguia detectar as diferenças, que na verdade existiam. Ou seja, se as mulheres seguissem a recomendação da pesquisa, corriam sério risco de desenvolver a neoplasia.

Já escrevi que, no que concerne as publicaçôes cientificas, todos somos culpados até que se prove o contrário. O número de equívocos cometidos em pesquisas, mesmos nos ensaios clínicos randomizados da área de saúde, extrapola o limite do aceitável e acaba por tornar o pesquisador um grande mentiroso, ainda que às vezes ele não o saiba. Sempre exigi dos meus alunos de especialização, mestrado e doutorado, avaliaçóes criticas de todos os autores citados e contextualizados respectivamente nas suas monografias, nas suas dissertaçóes e nas suas teses. Essa medida, de um certo modo, permite descobrir as verdades relativamente absolutas, vendidas para o público menos atencioso como verdades "verdadeiras".

Tentei também, em vão, em uma reunião dos editores de revistas na área de fisioterapia, defender a idéia da análise prévia dos autores citados nas referencias.

Diante de tamanha falta de evidências cientificas, mostradas nos mais diversos periódicos, inclusive no nosso, resolvemos que, a partir do próximo ano, só receberemos artigos de revisão bibliográfica que venham acompanhados com as avaliaçôes críticas de todos os autores estudados. Esperamos, assim, oferecer uma valiosa contribuição para os nossos leitores, que poderão ter a oportunidade de não se deixar guiar por resultados que estáo a léguas da verdade científica ou de qualquer verdade. 